Jpn. J. Ornithol. 48: 101-121, 1999

\title{
分子生物学的手法の鳥類保全への応用
}

\author{
永田尚 志 \\ 国立環境研究所・地球罟境研究グループ・野生生物保全研究チーム \\ ₹305-0053 茨城県つくば市小野川16-2
}

\section{The Applications of Molecular Techniques to Avian Biological Conservation}

\author{
Hisashi NaGATA \\ Laboratory of Wildlife Conservation, Global Environmental Research Division, \\ National Institute for Environmental Studies (NIES) \\ Onogawa 16-2, Tsukuba, Ibaraki 305-0053, Japan
}

\begin{abstract}
Human activities resulting from habitat loss and fragmentation have seriously threatened many birds and other fauna to the point of extinction. Almost $20 \%$ of bird species were categorized as either endangered or 'nearly threatened' species in 1996 IUCN Red data list. Recent advances in molecular techniques provide us with many tools appropriate to conservation in addition to the field of population biology. Allozyme analysis, DNA sequencing, minisatellite, microsatellite, and random amplified polymorphic DNA (RAPD) procedures enable us to identify parentage, pedigree, founder and bottleneck effects, population structure, effective population size, phylogenetic relationships among populations, as wll as gene flow within and between populations. Polymerase chain reaction (PCR) amplification of small amounts of DNA (nanogram), enable us to analyse genetic profiles without harming endangered birds. They also provide us with sophiscated techniques for analysis of metapopulation structure, hybridization, phylogenetic relationship within and between populations. All information regarding genetic population structure is important for the conservation of endagered bird species. In this review, I highlight the role of molecular techniques for studying bird population structures and for the effective planning of bird conservation strategies. Detailed knowledge of the relationship between genetic variation, environmental factors and fitness are all necessary if bird populations are to be successfully conserved.
\end{abstract}

Key Words: Avian conservation, Conservation genetics, Molecular techniques, Population structure

人間活動による生息地の分断化や消失によって，生物多様性が地球規模で消失の危機に

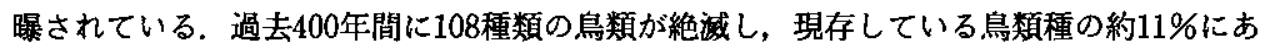
たる1107種類もが絶隇危惧種に分類され, 約 $9 \%$ にあたる952種が絶滅危惧種の予備軍に あたる保全依存種または準絶隇危惧種に分類されている(IUCN 1996). 日本国内におい ても14種類がすでに絶隇し，90種もの鳥類が絶隇危惧種に分類されている（環境庁自然保 
護局 1998).このままの人間活動を続けれれば, 大量の生物種が地球上から姿を消してしま うのは時間の問題である、種や個体群を絶滅に追い込んでいる要因を診断し，その要因を 取り除き，絶城を防ぐための実践的理論を構築する保全生物学という新しい学問分野が形 成されたのは1980年代のことであった，その後，多くの教科書が出版され（Frankel \& Soule 1981, Soule 1986, Primack 1993, Meffe \& Carroll 1994, Caughley \& Gunn 1996), 日本国内であ荤ればせながら1990年代中ごろになって相次いで教科書が出版され ている（桶口 1996, 觜谷・矢原 1996). 以前は, 笑験個体群や理論的にしか扱えなかっ た遺伝的問題が, 最近の分子生物学的手法の発達により, 実際の野外個体群において遺伝 的形質を特定できるようになったため，個体群保全における遣伝的な重要性が認識される ようになり，1990年代になり保全遺伝学の教科書が相次いで出版された（Loeschcke et al. 1994, Avise \& Hamrick 1995, Smith \& Wayne 1996). 保全遺伝学では, 逍伝的多 様性が個体群の存続期間に及ばす影幚や，人為的導入種との移入交雑による固有（亜）種 の消失のような遗伝的要因による種や個体群の絶減の問題を取り扱っている.

個体数の減少によって生じる人口学的確率性, 開発による生息環境の悪化などの環境要 因，括よび近交弱勢や遺伝的多样性の減少による繁殖力の低下などの遺伝要因は, 複雑に 絡み合って個体群や種の存続に影響を与える，そのため，遭伝的多様性を維持することが， 種や個体群の存続にとって十分条件ではないけれです，必要条件であり重要である．大規 模な開発により生息地そのあのが消失してしまうょうな色機的状況においては，遭伀的多 様性の保持のような個体群の長期的な維持を目的にすえることは悠長すぎるかるしれない． しかし, 分子生物学的手法は, 個体群の遗伝的多様性を維持するような長期的保全計画や 種の回復計画における初期の人口学的問題を明らかにするのには有効な道具である. まず, 種や亚種など保全の分類単位を同定するのに大きな力を発揮する.つぎに, 個体群間の跹 伝的分化の程度を解明することにより，保全を必要としている個体群を特定できる．さら に, 個体群構造を明らかにすることにより, 回復計画の早い段階から個体群の管理計画を 適切に立てることが可能になる。ここでは, 鳥類の保全に役立つ分子生物学的手法や保全 遭伝学の概要について簡単に紹介し，応用可能な分野について総説する．この小文が，鳥 類の保全において分子生物学的手法を利用する際の有効なマニュアルになることを期待す る.

\section{分子生物学的手法}

近年の生化学的手法の急速な発達によって分子生物学的手法を集団生物学や野生生物の 保全へ利用することが可能になった，集団生物学や保全生物学に利用される分子生物学的 な遺伝子マーカーとして使用されるのは，DNAから翻訳された䣼などのタンパク質の サイズ多型や核やミトコンドリアにあるDNA そのあのである (Table 1). 電気泳動法が 発達した1950年代に，アロザイム䣼素多型をもちいた集団の遗伝的な解析は確立し，多く の分類群で研究が行なわれた (Evans 1987). 電気泳動法で分子量の異なるバンドとして 表せるタンパク質の遗伝子座がアロザイムである. しかし，対立遺伝子数が少なく多型を 持つ道伝子座が少ないこと, 組織試料が必要で野外での長期保存が容易でなかったため, 他の分類群に比べて鳥類ではあまり研觉されなかった（Parker et al. 1998).一方, 


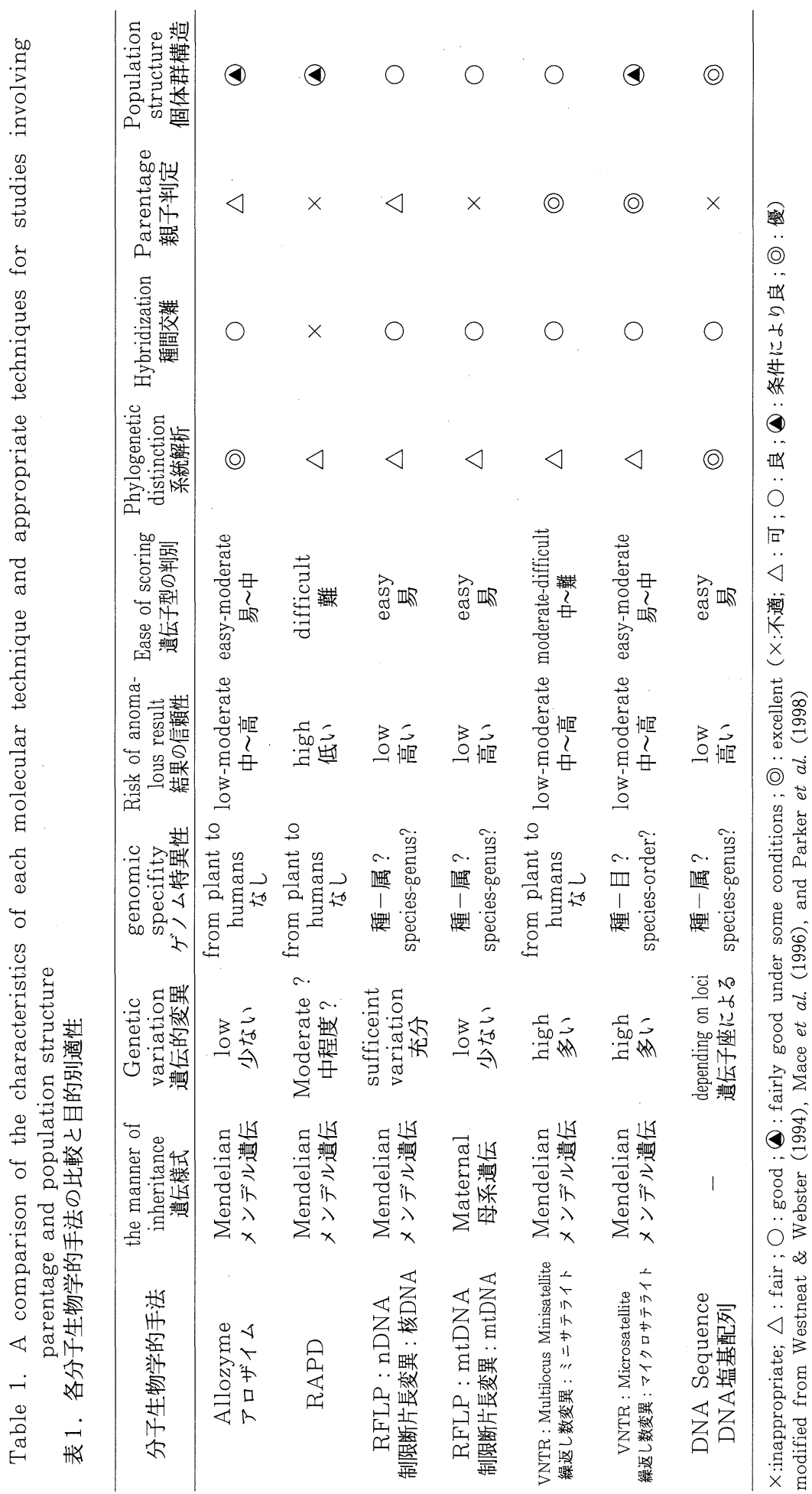


DNA はタンパク質に比べて安定した物質であり，野外でも適当な保存液を準備すれば常 温で長期間保存可能なこと，鳥類では赤血球に核が存在するため微量の血液から採取でき るため, 対象個体を殺さずに採取できる利点がある (Seutin et al. 1991, Parker et al. 1998). ポリメラーゼ連鎖反応 (PCR) 装置の発明と自動塩基配列読取装置（オートシー クエンサー）の発達で, 生化学の技術に熟練していないフィールド研究者にあ DNA 解析 ができるようになった (Haig 1998, Parker et al. 1998). DNAには, 細胞内器官であ るミトコンドリアが持っていて母親からのみ子に伝わる mtDNA と核内にあり両親から 半分のセットが子に伝わる核 DNAの 2 種類がある.

DNA を遺伝子マーカーとして用いる際, DNA 断片長やタンデムリピートの繰返し数 を間接的に遗伝情報として用いる方法と直接 DNA 塩基配列を読み取る方法がある.

RAPD (random amplified polymorphic DNA) や制限断片長变異 (RFLP: restriction fragment length polymorphism) は，無作為に合成された DNA 断片や制限酵素で切ら れた DNA 断片の長さを遗伝子マーカーとして利用している. また, Jeffreys et al. （1985）により，生物の DNA 塩基配列中にタンパク質に翻訳されないタンデムリピート とよばれる数十塩基の綝返し配列（ミニサテライト）が発見され，この反復数が個体によっ て大きく異なり，選択的に中立な部位であることから，ミニサテライト部位が集団や個体 群構造の解析に頻繁に利用されるようになった. ひとつの繰返し配列の長さが10-60塩基 対のあのをミニサテライト，2-6塩基対の短い綝返し配列をマイクロサテライトとよび, DNA 上の特定の場所のタンデムリピートの繰返し数の変異 (VNTR; variable number of tandem repeat) を遗伝子マーカーとして利用している. オートシークェンサーを用 いて，特定の場所の DNA 塩基配列（DNA sequence）を読み取り利用するのが最も情報 のロスは少ないが, 問題点もある (後述). 各マーカーの生化学的解析手法や原理につい ての詳しい説明は石田（1996）と西海（1997）を参照してほしい，集団生物学的解析にお いて遗伝的マーカーとして用いられるのは, アロザイム多型, 核DNA および mtDNA の 制限断片長变異 (RFLP), マイクロサテライトやミニサテライトとよばれる核DNAの タンデムリピート数の変異 (VNTR), および mtDNAの塩基配列である.

個々の遺伝子マーカーにはそれぞれ長所と短所がある（Table 1)。アロザイムは，多 型がある遺伝子座の場合は, 集団の遺伝的構造の解析には適している. マルチローカスミ ニサテライト遺伝子座などの制限断片長変異 (RFLP) やRAPD 法は, 複数の塩基配列 の断片長変異であるため, 集団間の類似性を調べるのには適しているが, 対立遺伝子を特 定することはできない，また，RAPD 法ではバンドパターンの出現が実験条件に依存す るため結果の再現性は低いが，特定のプライマーが必要ないため, 短時間に簡単に解析で きる利点がある（石田 1996），mtDNA は母系遺伝をするので，雄の寄与は全くないため， 親子関係の判定や家系解析にはあまり役に立たない，ただし，鳥類では主に倠が個体群間 を分散するので (Greenwood 1987)，遺伝子交流など集団間の遺伝的構造を調べるのに 適している，核DNA は，マイクロサテライトやミニサテライトなどの繰り返し配列をた くさん含み，メンデル遺伝をするため，親子判定や家系解析に適している．また，対立遺 伝子数が数個程度のマイクロサテライト遺伝子座は, 個体群構造の解析に最適である. 一 方, 対立遺伝子数が多く希な刘立遺伝子を含むマイクロサテライト遗伝子座は, 個体群解 析にはむかないが，親子判定には最適である．DNA 塩基配列の決定は，処理時間が長く 
分析費用が高いのが欠点だが，情報量が多く最も細かい遗伝構造の解析が可能である.

分子生物学的手法ごとにかかる分析コストをTable 2 に示した. アロザイム分析は，比 較的短時間で解析でき, 電気泳動装置さえあれ代可能であるので, 初期投資が少なくてす むうえ，1サンプルあたりの分析費用あ安い. しかし，組織標本が必要であるうえに遺伝 的変異が少ないため, 希少種の遣伝的解析にはむかない. DNAを遗伝子マーカーとして 利用する有利な点は, 羽毛 1 枚や数 $\mu \ell$ の血液等, 微量のサンプルさえあれば, PCR 法 により増幅して解析できる点である. しかし，DNA 分析はアロザイム分析に比べると習 熟が必要であり，薬品が高価なので分析費用は高くなる，RAPDやマイクロサテライト 遗伝子座の解析では，いったんルーチン化してしまえば，ランニングコストはそれほどか からないが，PCR 装置など百万円程度の初期投資が必要である，RFLP 法では，特定の 部位で DNA を切断する制限醳素が必要なため，分析費用が高くなる．また，RFLP法は， PCR 法を使わないので, RAPDやマイクロサテライト解析に比へて多量の試料が必要に なり, 分析に長い時間を要する. mtDNAなどの塩基配列の解析は, 薬品類が高価で分析 費用がさらにかかるうえに，一下万円近くあするオートシークェンサーが必要である (Westneat \& Webster 1994, Parker et al. 1998).

Table 2. A comparison of the expense and time consumption of each molecular techniquer to analyze DNA profiles.

表 2，各分子生物学的手法の分析に要するコスト

\begin{tabular}{|c|c|c|c|c|c|}
\hline 分子生物学的手法 & $\begin{array}{c}\text { Development } \\
\text { time } \\
\text { 開発に要する時間 }\end{array}$ & $\begin{array}{l}\text { processing time } \\
\text { per sample } \\
\text { 解析に要する時間 }\end{array}$ & $\begin{array}{c}\text { Equipment } \\
\text { 解析装真の值段 }\end{array}$ & $\begin{array}{l}\text { Opperating } \\
\text { supplies cost } \\
\text { 訊料の分析費用 }\end{array}$ & 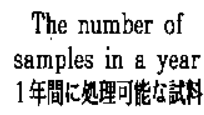 \\
\hline $\begin{array}{l}\text { Allozyme } \\
\text { アロザイム }\end{array}$ & $\begin{array}{l}2-4 \text { weeks } \\
(2 \sim 4 \text { 週間 })\end{array}$ & $\begin{array}{l}2 \text { days } \\
(2 \text { 日) }\end{array}$ & $\begin{array}{l}\text { Cheap } \\
(\sim 10 \text { 万円 })\end{array}$ & $\begin{array}{c}\text { Cheap } \\
\text { 安W(数百円) }\end{array}$ & $\begin{array}{l}\text { Sereral thousands } \\
\text { 数干 }\end{array}$ \\
\hline RAPD & $\begin{array}{l}1-2 \text { weeks } \\
(1 \sim 2 \text { 週間 })\end{array}$ & $\begin{array}{l}1 \text { week } \\
\text { (1 週間) }\end{array}$ & $\begin{array}{l}\text { Moderate } \\
(\sim 100 \text { 万円 })\end{array}$ & $\begin{array}{c}\text { Cheap } \\
\text { 女い(数百円) }\end{array}$ & $\sim 10000$ \\
\hline $\begin{array}{c}\text { RFLP } \\
\text { 制限断片長変異 }\end{array}$ & $\begin{array}{l}1-4 \text { months } \\
(1 \sim 4 \text { カ月) }\end{array}$ & $\begin{array}{l}2-4 \text { weeks } \\
(2 \sim 4 \text { 週間 })\end{array}$ & $\begin{array}{c}\text { Moderate } \\
(\sim 100 \text { 万円) }\end{array}$ & $\begin{array}{c}\text { Moderate } \\
\text { 中程度 (千円未渾) }\end{array}$ & $\sim 1000$ \\
\hline $\begin{array}{l}\text { Minisatellite } \\
\text { ミニシテライト }\end{array}$ & $\begin{array}{l}1-3 \text { months } \\
(1 \sim 3 \text { 月 })\end{array}$ & $\begin{array}{l}2-4 \text { weeks } \\
(2 \sim 4 \text { 週間 })\end{array}$ & $\begin{array}{l}\text { Moderate } \\
(\sim 100 \text { 万円 })\end{array}$ & $\begin{array}{c}\text { Moderate } \\
\text { 中程度 (千円未渶) }\end{array}$ & $\sim 1000$ \\
\hline $\begin{array}{l}\text { Microsatellite } \\
\text { マイクロサテライト }\end{array}$ & $\begin{array}{l}2-6 \text { months } \\
(2 \sim 6 \text { 力月 })\end{array}$ & $\begin{array}{l}1 \text { week } \\
\text { (1 週間) }\end{array}$ & $\begin{array}{l}\text { Moderate } \\
(\sim 100 \text { 万円 })\end{array}$ & $\begin{array}{c}\text { Cheap } \\
\text { 安い(数百円) }\end{array}$ & $\sim 10000$ \\
\hline $\begin{array}{l}\text { DNA Sequence } \\
\text { DNA塩基配列 }\end{array}$ & $\begin{array}{l}1-3 \text { months } \\
(1 \sim 3 \text { カ月) }\end{array}$ & $\begin{array}{l}2-4 \text { week } \\
(2 \sim 4 \text { 週間 })\end{array}$ & $\begin{array}{l}\text { The most expensive } \\
(\sim 1000 \text { 万円 })\end{array}$ & $\begin{array}{c}\text { Expensive } \\
\text { 高い (数干円) }\end{array}$ & 2500 \\
\hline
\end{tabular}

modified from Westneat \& Webster (1994) and Parker et al. (1998)

PCR 法によって DNA の特定の部位を增幅する際には, プライマーと呼ばれるDNA 断 片が必要である. マイクロサテライト多型解析やDNA 塩基配列の解析に必要な最新のプ ライマーの情報は, 国立遗伝研究所（1999）およびアメリカの国立衛生研究所（NIH 1999）において検索が可能である. 


\section{保全违伝学}

アメリカ大陸の絶隇危惧鳥類の個体数隇少の最あ大きな原因は, 大陸においても島懙に おいて開発による生息地の消失である（Collar et al. 1992）. 生息地が消失するにつれ て生息できる個体数が減少すると同時に，生息地の分断化がおこり，分集団が次々に消失 していき, 最終的に残った最後の集団が消失したときに, 種の絶滅が起こる (Fig. 1). 有効集団サイズを $N_{e}$ としたとき, 個体群中に保持されているへテロ接合度は, 1 世代あ たり $1 / 2 N_{e}$ の割合で減少していくので, 1 世代後のへテロ接合率の減少率 $\Delta H$ は,

$$
\Delta H=\frac{1}{2 N_{e}}
$$

となる. 最初のへテロ接合率を $H_{0}$ とすれば, $t$ 世代後のへテロ接合度 $H_{t}$ は次の式で求め られる.

$$
H_{t}=H_{0} \cdot\left(1-\frac{1}{2 N_{0}}\right) \cdot\left(1-\frac{1}{2 N_{1}}\right) \cdots\left(1-\frac{1}{2 N_{t}}\right)=H_{0} \cdot \prod_{i=0}^{t}\left(1-\frac{1}{2 N_{i}}\right)
$$

式 2 から明らかなように, 集団サイズが小さくなるほどへテロ接合度が急速に失われてし まうし，いったん集団サイズが小さくなると個体群が回復しても減少した多様性は回復し

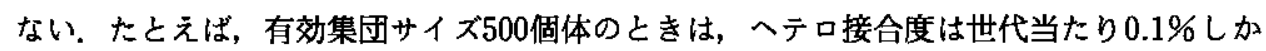
減少しないが，ある世代に有効集団サイズが10個体まで減少したとすると $5 \%$ \%のへテロ 接合度が減少してしまう。このように個体数が減少するにつれて, 遗伝的浮動の効果が大

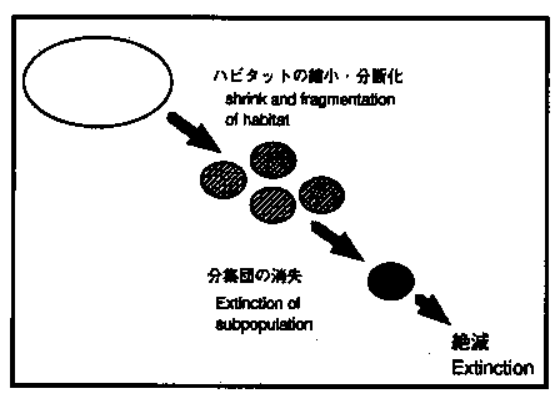

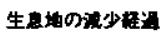

(The process of extinction resulting from habitat loss)

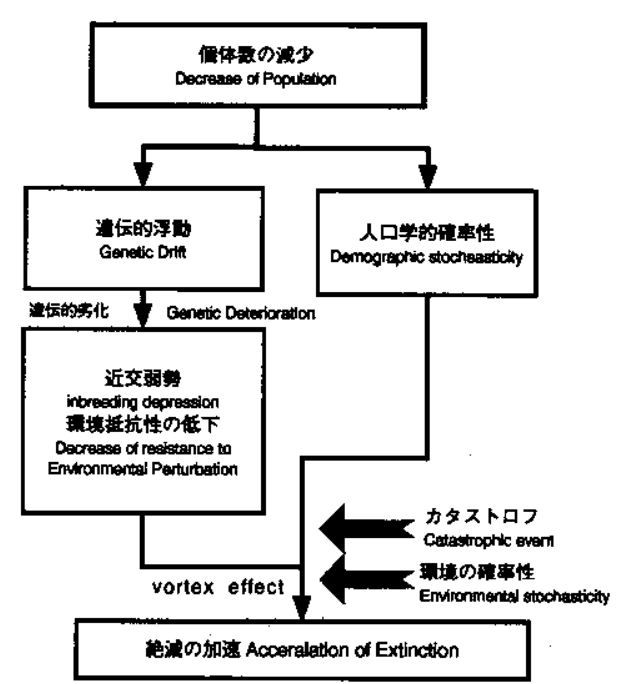

図1 ハビタットの隇少による絶隇プロセスと小集団化が絶减に影響を与える様々な要因

Fig. 1. Species extinction resulting from habitat loss, fragmentation, and reduced population size. 
きくなり遗伝的多様性は急速に失われる（Frankel \& Soulé 1981, 整谷・矢原 1996). 実際，いろいろな動物種の個体群サイズとへテロ接合率は正の相関関係を示し，個体群サ イズが小さくなるとホモ接合が増加している（Fig. 2) (Soulé 1976, Frankham 1996). 対立遺伝子の多様性の減少によって環境变動や病気への抵抗力をもつ遺伝子を失うばかり

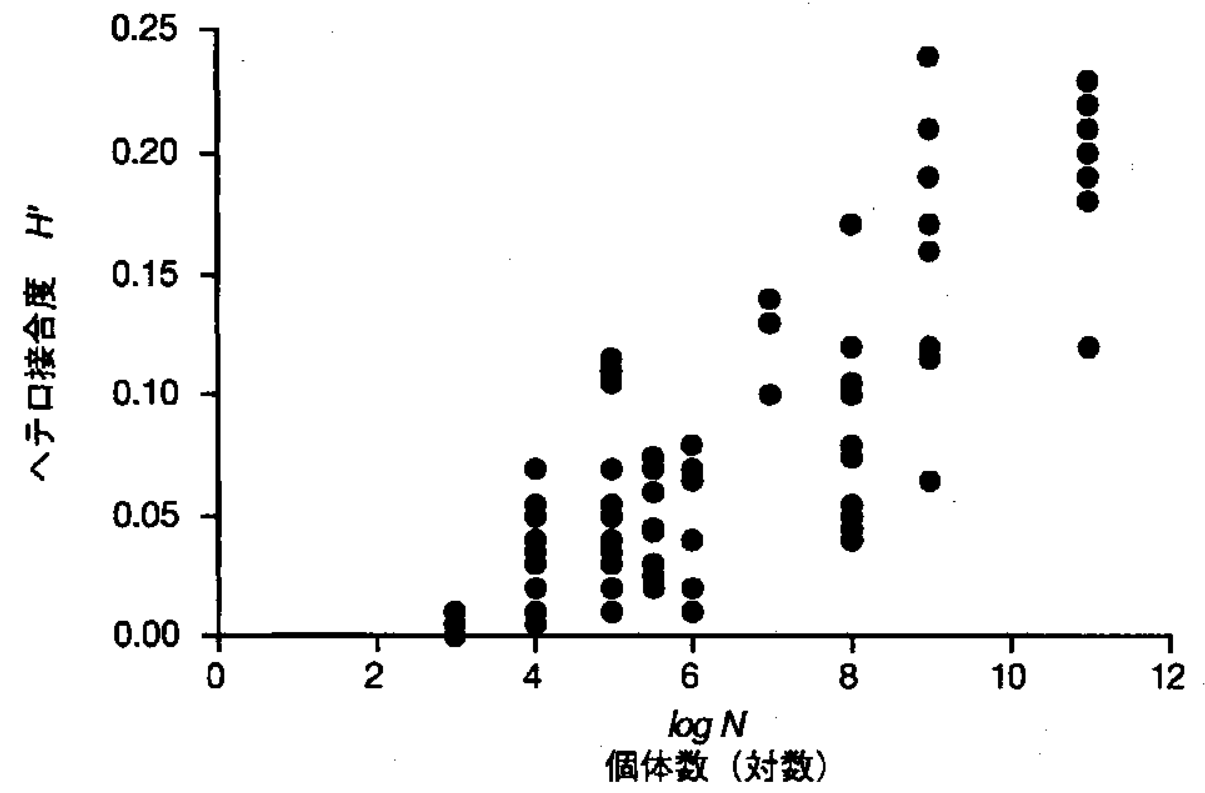

図 2 個体群サイズ $(\log \mathrm{N})$ とへテロ接合度 $\left(\mathrm{H}^{\prime}\right)$ の関係

Fig. 2. The correlation between heterozygosity ( $\left.H^{\prime}\right)$ and population size (logtransformed N) for animal species. (after Soulé 1976)

でなく，ホモ接合の増加により集団中に保持されている有害遭伝子が発現したり，超優性 遗伝子の効果がなくなるため, 個体群の生存力は低下する（Crow \& Kimura 1970)。 ま た，個体数の減少は人口学的確率性による絶滅の危険性を大きくする.10円硬貨をほうり 投げて表が出る確率は1/2であるが，100回の試行で，すべてが表または裏になることはほ とんぞ起こらない $\left(1.57 \times 10^{-28 \%}\right)$. しかし，3回の試行ならば，すべてが表または裏に なることが $25 \%$ の確率で生じる. 同様に, 個体数が減少すると, 平均の性比が $1: 1$ の鳥 類であっても偶然により雔の性比がどちらかに偏ってしまい絶隇する確率が生じやすくす る. 遗伝的浮動や人口学的確率性による絶隇の危険性の増大に加えて, カタストロフィッ クな天変地異が起これば小集団は簡単に絶威してしまう（Fig. 1)。すなわち個体群が小 さくなることによって遺伝的浮動, 人口学的確率性, 環境の確率性などが相互に悪影響を 及汇しあって，絶滅の可能性がより大きくなる(Primack 1993, Meffe \& Carroll 1994, Caughley \& Gunn 1996).

分子生物学的手法を用いた保全遺伝学に期待されているのは, 自然個体群がお互い息伝 的にどのくらい異なるのか，もし個体群の遺伝的多様性が減少しているとすれば，近親交 
配によるものなのか, 過去の急激な個体数の減少（ボトネネック効果）によるものなのか を明らかにし，当該の個体群が本当に環境変動に対して絶隇しやすい状態にあるのかに答 えを出すことである．保全遺伝学で主に扱うのは，分断化や小集団化でおこる遺伝的多様 性の诚少や個体群間の遺伝子交流の程度, 種の境界之種間交雑の程度, 個体の親子関係と 近縁度などの問題である (Avise 1996). 分子生物学的手法を用いることにより, 各個体 のもつ個々の対立遣伝子を特定できるため, 多型遺伝子座の割合 $P$, 多型遗伝子座あたり の平均対立遗伝子数 $A P$, 遁伝子座当たりの平均対立遺伝子数 $A$, 有効対立遗伝子数 $A 0$, ヘテロ接合をしている遺伝子座の割合 $H_{\circ}$ などが, 種内および個体群内の遺伝的多様性を 表す尺度として用いられる．個体群間の遭伝子頻度の類似度 $I$ から個体群間の遗伝的距離 $D$ が，遗伝子頻度の個体群間の分散 $F_{s t}$ から個体群間の間接的な遺伝子交流 $N m$ がもとめ られる (付表). その詳細は, Avise \& Hamrick (1995) とNei（1987）を参照してもら いたい.

\section{分子生物学的手法の応用分野}

\section{1）個体群や種の同定}

実際に種や個体群の保膵策をたてる際に，まず行なわなければならないのは，保全すべ き種, 亜種, 個体群の定義である. 保全の単位として適当なのは, 分類種（生物種）では なく, 系統種である. 現存の約 9000 種を系統種で分類しなおすとすれば, 2 万種になると 推定されている (Martin 1996). 系統種の識別には, 分子生物学的手法が必要不可欠で ある、また, 個体群が存続できないくらい個体数が減少したときに, どの個体群をひとつ にまとめて保全す心゙きか, どの個体群から個体を補充すべきかという議論において, 分子 生物学的証拠が明快な指針を与えてくれる，また，投入できる保全努力に制限があるとす れば, 分子生物学的手法加ら得られた系統樹を用いて, 進化遗伝学的にもっとも対象分類 群に貢献している種を選択して保全すべきであるという議論がされている（Krajewski 1994).

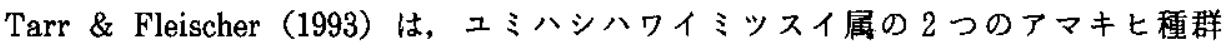
(Amakihi complex) Hemigrathus virens の mtDNAを解析した結果, $H . v$. chloris と H. v. stejnegeri は別種であり，個別の保全策をたてるべきであることを明らかにした. また, フロリダの一部にのみ生息していたクロハマヒメドリ Ammodramus maritimus nigrescens は, 形態的にハマヒメドリA. maritimus と異なっていたため別種とされたり 亜種と分類されたりしていたが, 絶隇後の mtDNA 解析の結果, クロハマヒメドリは八 マヒメドリの大西洋岸型と同一の遗伝子型を持っていることがわかり, 同種であることが 確認された (Avise \& Nelson 1989). 1980年にクロ八マヒメドリは飼育下の 5 羽の雄し か生存していなかったが, ハマヒメドリのメキシコ湾岸亜種の倠との亜種間交配で倠を得 た後に，戻し交配を繰り返し，クロハマヒメドリを復活する計画が開始された．残念なが ら,クロハマヒメドリの遗伝子を $87.5 \%$ 持つ雑種を得た1987年に, 最後の雄 1 羽が死んで しまい, 復活プログラムは失敗した。この例では, 異なった遺伝子型の塜種が交配相手に 選ばれたことが失敗の原因のひとつであり, 同じ遺伝子型の亜種を選ぶべきであったと指 摘されている (Zink \& Kale 1995). 


\section{2 ）種間交雑 : 遺伝子污染の問題}

鳥類では，野外においても種間交雑が頻繁に生じ，約10\%の種で捻性のある種間雑種が できるといわれている (Grant \& Grant 1992).とくに, 陸ガモ類のマガモ (Anas) 属 では，種間交雑を避けるしくみが求愛ディスプレーのみであるため種間雑種が生じやすい (Lack 1974). 人為的に世界中の湖や池に尊入されたマガモAnas platyrhynchos が， そ の地域の固有のAnas 属のカモと交雑を起こしている，アロザイム分析の結果，オアフ島 ではマガモとの交雑が進んだ結果，ハワイガモA， wyvilliana独自の対立遗伝子が消隇し てしまい，純粋なハワイガモはほとんどいない（Browne et al. 1993）。また, mtDNA の解析の結果, ニュージーランドのマミジロガモ A. superciliosaです, 純粋な個体は南 島の一部にほんの $5 \%$ \%ぼ残っているにすぎない (Rhymer et al. 1994). 北米からョー ロッパに導入されたアカオタテガモOxyura jamaicensis す, 在来種のカオジロオタテガ モ O. leucocephala と種間交雑を行ない, 在来種への影響が大きくなったため, アカオ夕: テガモと雑種個体の駆除が行なわれている（Williamson 1996）．最近，ニシアメリカフ クロウStrix occidentalis とアメリカフクロゥS. variaの種間交雑む問題になっている (Harmer et al. 1994). 分子生物学的研究は始まったばかりであり, 脊椎動物以外では 研究例が少なく，人為的導入種と在来種との交雑があまり問題になっていないが，今後， 増えてくると考えられる (Haig 1998).

\section{3）性判定}

鳥類では外見上雌雄の区別がつかない種す多いが, 最近, Ellegren（1996）によって走 鳥類を除くほとんぞの種で利用可能なW 染色体上の遺伝子マーカーが発見され，容易に 性判定ができるようになった。 アオコンゴウインコCyanopsitta spixii は，1995年現在， 眗育個体を含めて32羽が生存しているが, 野外には性別不明の 1 羽が生存していただけで あった．この野外個体の換羽で脱落した羽から DNA を抽出し性判定を行なったところ， 雄と判定されたので，すぐに雌が放たれた（Griffiths \& Tiwari 1995).この例のよう に, DNA を使った性判定は，飼育下でっがい形成を行なう時や（Murata et al. 1998), 希少種の野外個体群に適切な個体を導入する際に役に立つと考えられる.

\section{4) 家系および近縁度の解析}

分子生物学的手法のもっとる大きな貢献は，社会生物学や行動生態学の分野において実 際の親子関係か判定できるようになったことである (Westneat \& Webster 1994)．遗伝 子マーカーをもちいた個体識別ができるようになったことで, 一夫一妻の種が 9 割を占め ると考えられていた鳥類です婚外授精が普通にみられることが明らかになった (Birkhead \& Møller 1992). 希少鳥類を眗育下で繁殖させて個体群を維持する際には, 眗育個体群の親子関係を完全に把握することにより, 近親交配をさけ, 飼育個体群の遺伀 的多様性を維持する必要である.

ホオアカトキGeronticus eremita は，16-17世紀には中央ヨーロッパ，北アフリカ，中 近東に広く分布していた，ヨーロッパでは狏厓と農薬によって個体数が激減し，1989年 にトルコで最後の個体が死亡したことにより，ヨーロッパの野外個体群は絶诚した。現在， 野外では，アフリカ北西部モロッコには200羽ほどが生息し，北イエメンで1989年に 9 羽， 
サウジアラビアで最近24羽が見つかっているだけである．しかし，IUCN の飼育下繁殖専 門家グループの協力でケージ内飼育が成功し，現在，800羽ほどの飼育個体群が存在して いる (Cramp 1977). Signer et al. (1994) は, チューリッ七動物園の家系がわかって いる39羽の飼育個体をミニサテライトDNAを用いて家系分析を行った. その結果，分子 生物学的手法之飼育記録による家系分析の結果が一致し，分子生物学的手法が飼育個体間 の近縁度を知り，個体群の遗伝的変異を調べる強力な道具となることが証明された.

グアム島では, 第 2 次世界大戦中に侵入したナンヨウオオガシラ Boiga irregularis と いうへビにより，11種の固有種のうち７種までが絶堿してしまった（Savidge 1987）。 ア メリカ野生生物局は, 1984年に野外に残っていた21羽のグアムクイナRallus owstoni と, 29羽のズアカショウビンHalcyon cinnamomina cinnamomina 全個体捕獲し、飼育下 での増殖を開始した．アロザイムとミニサテライトDNAを用いて捕獲された個体の近縁 度を解析し(Haig \& Ballou 1995), 近親交配による遺伝的多様性の減少が生じないよう に注意深く繁殖プログラムが組まれた．その結果，グアムクイナでは最初に捕獲した21個 体の持っていた遣伝的多様性の $89 \%$ が維持されている，グアムクイナの増殖は成功し，個 体数が190羽までに回復したため，1994年に一部をナンョウオオガシラのいないロタ島に 再導入し，野外個体群を確立した，再導入する個体は，コンピュータによる遺伝子座追跡 シミュレーションを用いて, 遗伝的多様性を維持できるように注意深く選ばれた（Haig et al. 1990). 1995年にロタ島に導入された個体の繁殖が最初に確認され，すこしづつで はあるが個体数を回復しつつある(AZA Species Survival Plan 1998).

\section{5) 個体群構造の解析}

分子生物学的手法を用いた DNA マーカーがもっとも威力を発揮するのは，個体群間お よび個体群内の集団構造の解析においてである (Barrowclough \& Gutierrez 1990, Haig et al. 1993, Haig et al. 1994, Fleischer et al. 1995, Haig et al. 1996). 各遺伝子座 の対立遗伝子頻度の個体群間の共有率の情報を用いて集団間の遗伝的な距離, 有効集団サ イズ，移出入率を推定することが可能になる．マルチローカスミニサテライトDNAを使っ た RFLP 解析においては，遗伝子座を特定することはできないので，バンドの共有率を 使った個体群構造の解析が行なわれた. Haig \& Avise (1996) は, 絶堿危惧種ではバン ドの共有率が高く，絶滅の危険がない種に比べて遺伝的な類似度が高いことを指摘してい る (Fig. 3).

まず、ミニサテライトDNA マーカーを用いた個体群構造の解析例を2つ紹介する，現 在, 北欧に生息している $3 \sim 5$ 万羽のカナダガン Branta canadiensis は, 1930年代に移 入された 5 羽から増えたものである．5 羽のうち，4 羽はドイッのハーゲンベック動物園 で飼育されていた個体で，1羽が北米から輸入されたあのである. ミニサテライト DNA を用いた解析で, 北欧のカナダガンはバンドの共有率が高く, 最初に導入された 5 羽の個 体が近親交配をくりかえして生じた個体群で, 他からの個体の移入がなかったことを示し ていた (Fig. 4; Tegelström \& Sjöberg 1995).

アオガモ Hymenolaimus malacorhynchos は, ニュージーランドの渓流にのみ生息す る希少種で, かってはニュージランド全土に広く分布していたが, 森林が農地や牧草地に 変わっていくにしたがって隇少し，現在では，分断化された小さな個体群のみになってい 


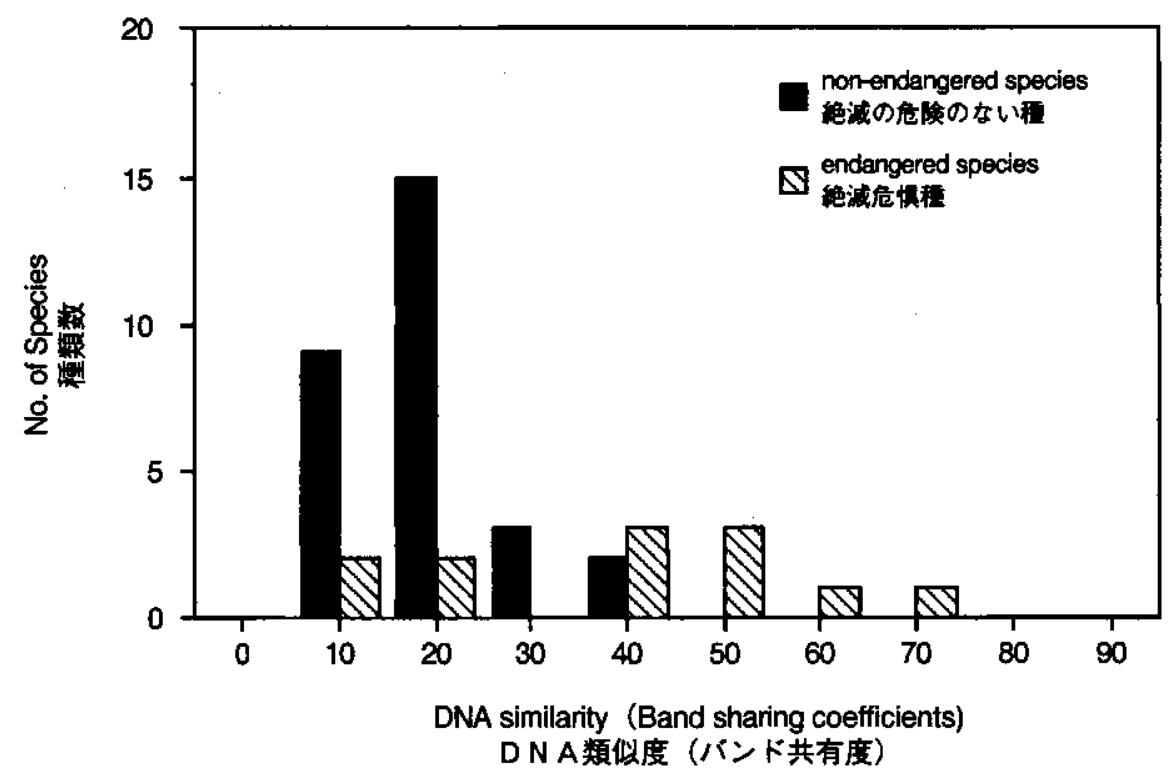

図 3 絶減危惧種之普通種のミニサテライトDNAのバンド共有度の頻度分布

Fig. 3. A frequency distribution of mean band sharing coefficients (DNA similarity) for non-endangered and endangered bird species. Bnad shring coefficient were calculating as the number of shared band divided by the total number of bands from conspecific individuals. (after Haig \& Avise 1996)

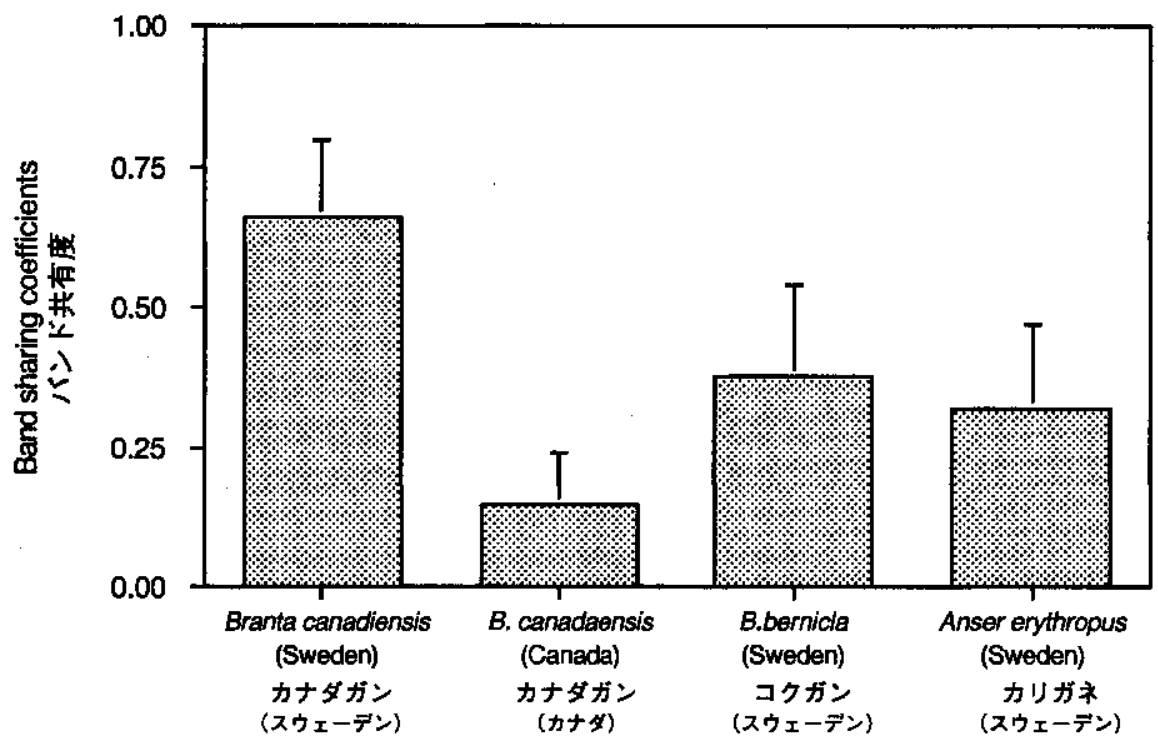

図 4 ガン類の種問おょび地域間のバンド共有度. 図中の䋛棒は標準偏差 (SD) を示している

Fig. 4. The mean band sharing coefficients among different species of geese on different geographic scale. Vertical bars show SD. (modified after Tegelström \& Sjöberg 1995) 
る，標識個体の追跡調查では，河川間の分散は少なく，ほとんどの個体が出生地の近隣に 定着していた（Williams 1991）。このアオガモの個体群構造をミニサテライト DNAを用 いて解析したところ，河川流域内ではバンドの共有率が高く遺伝的交流が認められるが， 地域間ではバンドの共有率が低くほとんど移動分散がなく，隣り合った河川間で少しの遺 伝的交流があることが推定された（Fig. 5; Triggs et al. 1992）

次に, マイクロサテライトDNAを用いた個体群の遗伝的構造の解析として, レイサン

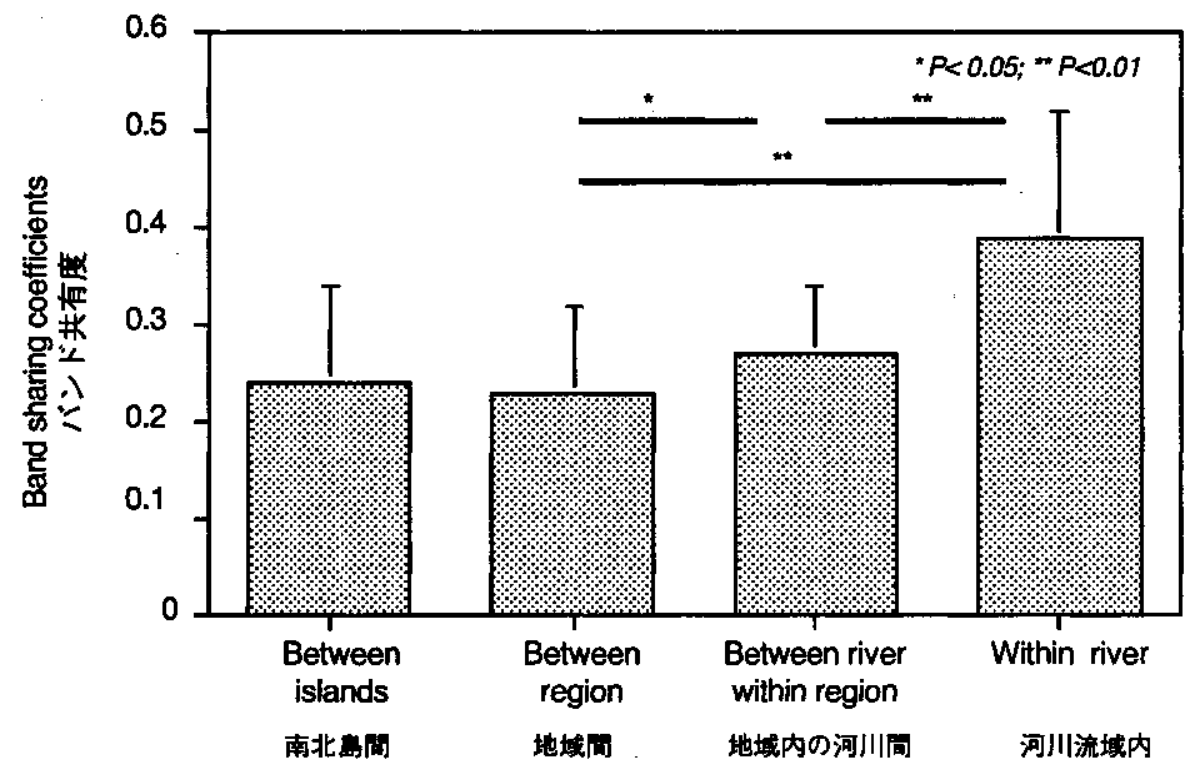

図 5 アオガモの地域間の遗伝的類似性. 図中の縦棒は標集偏差（SD）を示し, 横棒はカテゴ リ一間の比較を示し，アステリクスの数が統計上の有意水準を示す

Fig. 5. The mean band sharing coefficients within and between populations of Blue Duck in New Zealand. Vertical bars show SD, horizontal bars show comparsons between categories, and number of asterisks shows the statistical significance level (modified after Triggs et al. 1992)

ハワイマシコTelespiza cantansの例を紹介する，マイクロサテライト DNAを用いた解 析では，対立遺伝子を特定して記述すること（スコア化）が可能である.レイサンハワイ マシコは，レイサン島にのみ生息し，1923年には100羽程度しか生存していなかったが, 個体群住急速に回復して1968年に10,000羽程度になった。レイサンハワイマシコを保全す るために，アメリカ野生生物局は1967年にレイサン島の約 $300 \mathrm{~km}$ 北西に位置する Pearl and Hermes 環礁の Southeast 島に108個体を導入し，新しい個体群を創設した（Fig. 6). 導入直後は30 50羽にまで娍少したが，固体群は回復して500羽前後で安定した，また近 くにある North 島とGrass島にも自然に定着し増加した。これらの島のレイサン八ワイ マシコの遗伝的多様性を 9 種類のマイクロサテライト遣伝子座を用いて解析した結果, 各 遗伝子座で創始者勃果と遺伝的浮動による遺伝子頻度の変化が生じていて，レイサン島の 


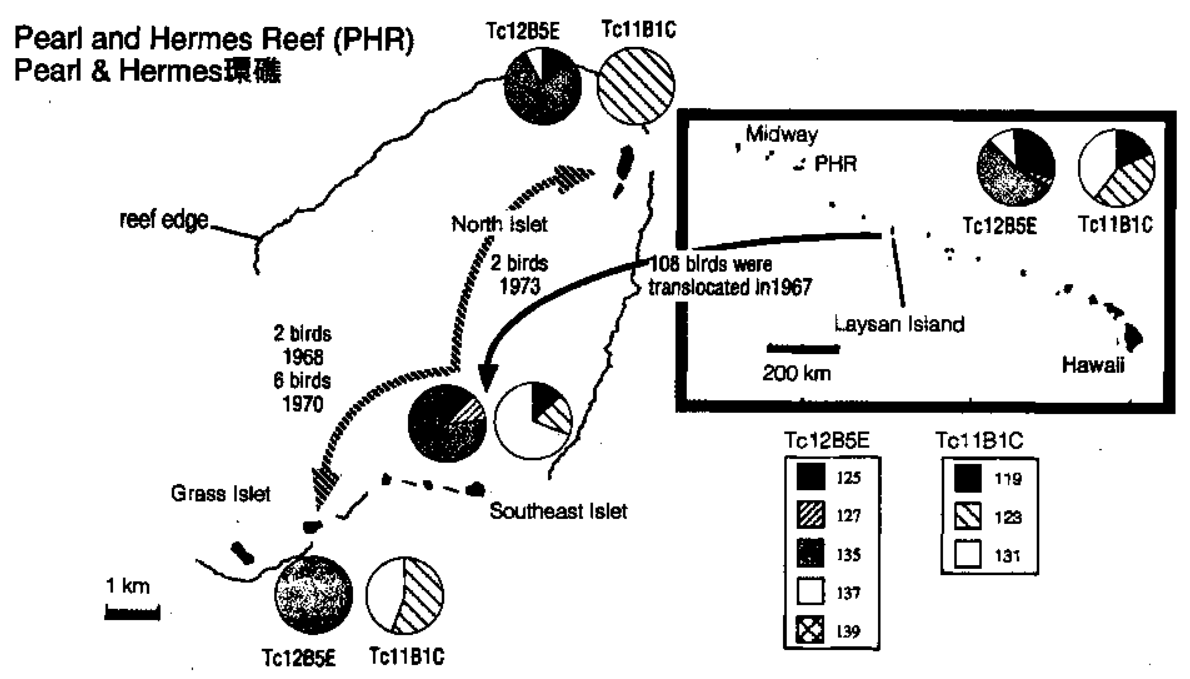

図6 Pearl and Hermes 環礁に導入さ杖レイサンハワイマシコの2つの遣伝子座の対立 倳伝子頻度（右円：遗伝子座 Tc11B1C, 左円 : 速伝子座 Tc12B5E). 破線矢印は, 導入 後に Southeast 島から，環礁内の North 島と Grass 島に自然に個体が定着した様子を 示している

Fig. 6. A map of Pearl and Hermes reef, showing the colonization history of three finch populations, and geographic representation of allele frequencies for two microsatellite loci [Tc12B5E (left circles) and Tc11B1C(right circles)] in each popilation. A solid arrow shows intoroduction of birds from Laysan island, and broken arrows show migration within the reef. (modified after Tarr et al 1998)

遺伝的多様性をすべて保存することはできていなかった（Tarr et al. 1998）. Pearl and Hermes 環礁の生息地の総面積は $34 \mathrm{ha}$ しかなく，有効集団サイズが 9 30個体と小さく， 遗伝的多様性の減少がさけられないため，時々，レイサン島から個体を移入してやること で遗伝的多様性を保つ保全策が必要であると結論された。この例のように数個程度の対立 遗伝子数を持つマイクロサテライト遺伝子座は，過去に受けたボトルネック効果の程度や 有効集団サイズを推定するのには役に立ち, 遺伝的多様性の観点から個体群の保全策を検 討するための強力な道具となる.

\section{6)個体の移動分散}

個体の移動や分散を直接推定するために, 多くの研究者が繁殖調査で巣内雊や成鳥に足 輪をつけて研究を行ってきた (Lebreton 1993). コロニーで繁殖する鳥類では，複数の コロニーを集中的に調查すれば, コロニー間の移動を調べることが可能だが, 非コロニー 性の鳥類では, 調查地以外への遠くへの分散は発見されにくくなる．このように，標識調 查では，観察された分散と実際の分散の間には差が生じる (Crochet 1996). 分子生物学 的手法を使えば間接的に個体群間の遺伝子交流を推定することが可能である（Edwards 1992). 個体群間の遺伝的変異の程度 $F_{s t}$ が得られれば, 1 世代あたりの集団間の移動個 
体数 $(N m)$ は次の式で算出される（Wright 1931）.

$$
N m=\frac{1-F_{\mathrm{ST}}}{4 F_{\mathrm{ST}}}
$$

レイサンハワイマシコの例（Tarr et al. 1998)では, Southeast 島-North 島間の $F_{\mathrm{ST}}=$ 0.266であるので 1 世代当たり0.7個体が移動分散し，同様に Southeast 島-Grass 島間で

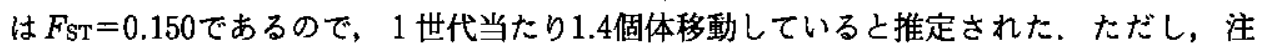
意しなければならないのは, 標識個体による直接推定と個体群間の遗伝子頻度加ら推定さ れる移動分散の間接推定值とでは, 時間的スケールが異なることである (Crochet 1996). 分子生物学的手法からの間接推定值は, 過去数十世代の平均有効分散個体数を示している のに刘し，直接推定では，短期間に観祭された繁殖しなかった個体の分散を含むすべての 分散個体数であることに留意する必要がある。

個体が供給源（ソース）ハビタットから条件の悪いシンクハビタットへ供給されるよう な個体群構造を持つ場合, 対象種を保全するためにはソースハビタットを保護する必要が ある. Dias et al. (1996) は, シングルローカスミニサテライト遺伝子座を使ってアオ ガラParus caueruleusのハビタット毎の対立遣伝子頻度を推定して, ハビタット間の遗 伝的差異の程度からシンク・ソース個体群関係を判定した. シンク・ソース構造を持つ個 体群では, 遺伝子流動はソースーシンク間〉ソースーソース間〉シンクーシンク間の順に少な くなるので，集団間の $F_{\mathrm{ST}}$ は逆にシンク・シンク間で一番大きくなった．また，シンク八 ビタットには，たえず新しい個体が移入してくるため, ハーディ・ワインベルグ平衡に達 していないので連鎖不平衡が生じていた.

\section{7）渡りの経路や越冬地}

繁殖地と越冬地間を長距離渡り, かつ広く分布している鳥種では, 個体群の繁殖地, 中 継地および越冬地を特定することが困難である。 マナッ゙ルGrus vipioやオオワシ Haliaeetus pelagicusのような大型鳥類では, 人工衛星を使った追跡で渡りのルートを解 明することも可能だが (Higuchi et al. 1994a, Higuchi et al. 1994b, Ueta et al. 1998), 小型の渡り鳥では発信器を装着することは不可能である，繁殖地で大量標識して標識個体 を追跡する方法が世界中で行なわれてきた（Lebreton 1993）が, 標識場所から分散して

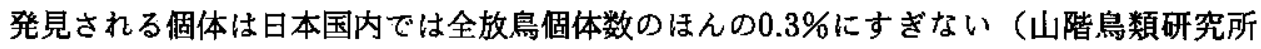
1997). 最近, 越冬個体群と繁殖個体群の遺伝的類似度や特定の個体群に特異的な遗伀的 マーカーを使って, 繁殖地と越冬地を結びつける研究が行なわれている. Haig et al. (1997) は, 北アメリカ大陸のハマシギ Charadrius alpina, アメリカオオハシシギ Limosa haemastica などの中・小型の啮离類10種類を繁殖地, 渡りの中継地, 越冬地で 捕獲し，血液や組織から DNA を抽出し， RAPD 法で捕獲地間の遗伝的類似性を調べた。 その結果, RAPD法で得られた電気泳動のバンドパターンの類做性から，渡りのルート や繁殖地と越冬地の関係を推定することができた. アメリカオオハシシギとハマシギは, アラスカとノースウェストテリトリーのハドソン湾岸で繁殖し, ハマシギはカリフォルニ アとメキシコ湾岸で越冬し，アメリカオオ八シシギはアルぜンチンで越冬する．秋にサス カチュワン州を通過するアメリカオオハシシギの個体群はマニトバ州のチャーチルからで 
はなくマッケンジーデルタから来ていると考えられ，春にサスカチュワン州を通過する八 マシギ個体群は, マニトバのチャーチルではなくアラスカのプルドー湾へ渡っていること が推測された (Fig. 7). また, Bensch \& Hasselquist（1999）は，ヨーロッパで繁殖し ているオオョシキリ Acrocephalus arundinaceus の6つの繁殖個体群と 1 つの越冬個体 群（ケニア）で捕獲した106羽から血液を採取し, mtDNAのコントロール領域（494塩基 対）を解析した. その結果，33種類の遁伝子型が発見され，2つの系統群（クレード）に 分類された。系統群 $\mathrm{A}$ と B 2 群の塩基配列の違いは, 全配列の $1.29 \%$ であり，70,000年 前に分かれたと考えられた。 クレード B は，ヨーロッパ東部でのみみられ，その割合が 東にいくにしたがって增加した（Fig. 8). また，ヶニアではクレードBを持つ個体群し か越冬していず， ヨーロッパの東部と西部で繁殖する個体群の越冬地が異なることが推定 された。ここで紹介した例のように, 分子生物学的手法を用いることによって, 渡り鳥の 移動の経路や越冬地を推量することは可能である. 分子生物学的手法から得られた渡りの 経路の推量の証明は，実際に標識された個体が発見される必要がある。この作業も大変な ことにはかわりないが，全く予测できない経路から標識個体を探すよりは可能性が高いで あろう，渡り鳥の保全には，繁殖地だけでなく中継地と越冬地の保護す重要である.
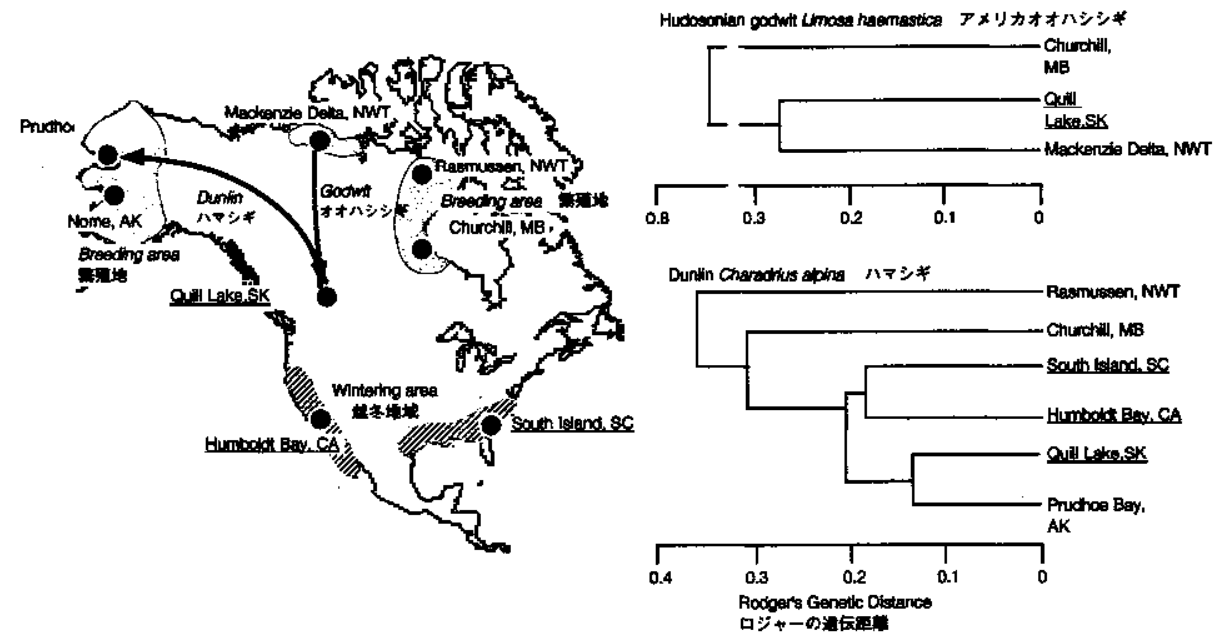

図 7 北アメリカのシギ類の繁殖地, 越冬地 (下線), 中継地（2 重下線）の個体群の速伝的距 離から椿筑したデンドログラムとの採集地点の地図

Fig. 7. A distribution map of sampling sites and the results of a UPGMA cluster analysis for Rodger's genetic distance among breeding, migrant (doubleunderlined) and winter (underlined) populations of Hudsonian Godwit and Dunlin. (Modified after Haig et al. 1998) 


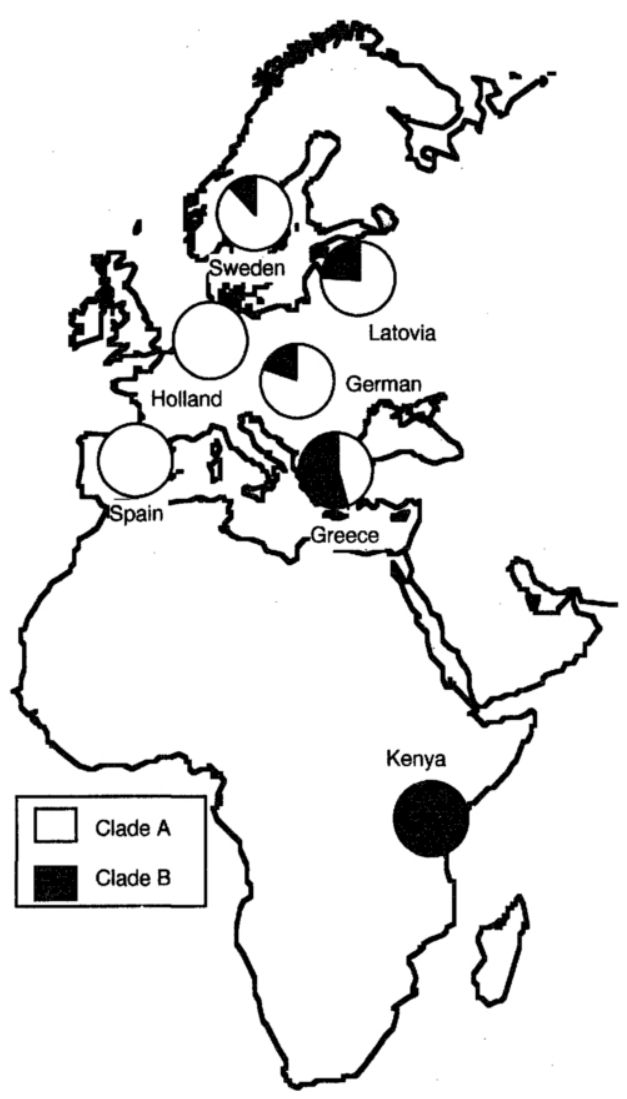

図 8 オオョシキリの個体群毎のミトコンドリアDNAの遺伝子型の頻度の分布図

Fig. 8. A map showing the distribution and relative frequency of clade $\mathrm{A}$ (white) and clade B (Black) mtDNA haplotypes for the six European breeding populations and one Kenyan wintering population of the Great Reed Warbler. (after Bensch \& Hasselquist 1999)

\section{さいごに}

この総説では，分子生物学的手法を用いて，保全すべき系統の特定，家系分析，集団内 および集団間の遺伝的構造，集団の移動分散などが推定できることを紹介し，この手法が どのように鳥類の保全生物学に役立つ道具となりうるかを具体的に示した. どんな生物む いつかは必ず絶滅するので, 保全生物学のゴールは, 単に種を絶滅しないように保存する ことではなく，継続した進化が起こりうる条件下で自然界の種や群集を長期間保つことに ある (Frankel \& Soule 1981). たくさんの遺伝的変異を持っている生物こそが絶えず変 化し続ける環境に適応できるであろうから, 個体群の長期間の存続のためには, 遺伝的多 様性が重要であると考えられる。これまで多く用いられてきたマイクロサテライトやミニ サテライトとよばれる反復 DNA は，機能を持たない遺伝子であるため，自然選択上は中 
立である. 研究者は, 暗然のうちに中立な遺伝子座のふるまいと機能している遺伝子のふ るまいに相関があり, 中立な遺伝子座の多様性の減少によって適応度が減少することを期 待している，鳥類においては，中立な遺伝子座の多様性の減少と適応度の関係を研究した 例はほとんどない. 今後, なるべく多くのマイクロサテライト遺伝子座を調べて個体あた りのへテロ接合度の平均之適応度の関係および集団のへテロ接合度と個体群の適応度の関 係を明らかにする必要がある. 免疫防御反応に影響を与える主要組織適合性抗原複合体 (MHC) 多型は, いろんな病原菌に対する抵抗性に直接に相関している (Hill 1991). そ のため, 直接, 集団の生存力を測定するには MHC 多型の変異と適応度の関係を研究する のが適当かもしれない.

分子生物学的手法を用いることによって, 保全すべき集団の特定, 移植候補個体群の同 定, 移植後の個体群の遺伝的モニタリング, 飼育化個体群の遺伝的多様性の管理, 個体群 の遺伝的存続可能性の解析, 渡りの経路の推定などが, 鳥類の保全に応用できる. 複数の 分子生物学的手法を併用することにより, より精度の高い結論を得ることができるだろう. これらの分子生物学的手法で得られた情報は, 野外での個体群生態学, 行動生態学, およ び生理学的研究といっしょに使われたときに最あ威力を発揮できるであろう. DNA 解析 は, 分析費用が高く, ある程度の熟練が必要なため, 多くの野外鳥類研究者にとってまだ 敷居が高いかもしれないが, 今後, 分子生物学の技術革新によってもっと簡単に解析でき るようになるであろう. 分子生物学的手法を使った個体群の遺伝的構造の解析が鳥類の保 全に大きく貢献することはまちがいない.

北九州で開催された鳥学会シンポジゥムに招待し本稿を書く機会を与えていただき, 本稿ができ上 がるのを辛抱強く待っていただいたシンポジゥム実行委員長の江口和洋博士に厚く御礼を申し上げる. また, 本稿をまとめるにあたって, 農業研究センターの吉田保志子氏および, 2 人の匿名の校閲者か ら草稿に対して適切な助言をいただいた，石田俊子氏には文献の収集と整理を手伝っていただいた。 また, STA フェローとして国立環境研究所に滞在している Stewart Plaistow 博士には英語をみて いただいた。これらの方々に心より御礼申し上げる.

\section{引用 文 献}

Avise, J. C., 1996 Introduction: The scope of conservation genetics, Avise J. C. and Hamrick J. L. (eds.) Conservation Genetics-Case histories from nature-: 1-9, Chapman \& Hall, New York.

Avise, J. C., and Hamrick, J. L., 1995 Conservation Genetics: Case history from nature. Chapman and Hall, New York.

Avise, J. C., and Nelson, W. S., 1989 Molecular genetic relationship of the extinct dusky seaside sparrow. Science 243: 646-648.

AZA Species Survival Plan, 1998. GUAM RAIL 98 Fact Sheet (9/1/98) . Guam. [news letter posted on the World Wide Web]. Retrieved September 1, 1998 from the World Wide Web: http://aza.org/Programs/SSP/ssp.cfm?ssp=41.

Barrowclough, G. F. \& Gutierrez, R. J., 1990 Genetic variation and differentiation in the spotted owl (Strix occidentalis). Auk 107: 737-744.

Bensch, S. \& Hasselquist, D., 1999. Phylogeographic population structure of great reed warblers - an analysis of mt DNA control region. Biol. J. Linn. Soc. 66: 171-185.

Birkhead, T. R. \& Møller, A. P., 1992. Sperm competition in birds: Evolutinary cause 
and consequences. Academic press, London.

Browne, R. A., Griffin, C. R., Chang, P. R., Hubley, M. \& Martin, A. E. 1993. Genetic divergence among populations of the Hawaiian duck, Laysan Duck, and mallard. Auk 110: 49-56.

Caughley, G. \& Gunn,A., 1996 Conservation Biology in theory and practice. Blackwell Science, Cambridge, Massachusetts.

Collar, N. J., Gonzaga, L. P. \& Krabbe, N. 1992 Threatened birds of Americas. ICBP, London.

Cramp, S., 1987. Handbook of the birds of Europe and the Middle East and North Africa. The birds of the western Palearctic. 1. Ostrich to Ducks., Oxford University Press, Oxford.

Crochet, P. A., 1996 Can measures of gene flow help to evaluate bird dispersal? Acta Oecol 17: 459-474.

Crow, J. F., and Kimura, M. 1970 An introduction to population genetic theory. Harper and Row, New York.

Dias, P. C., Verheyen, G. R. \& M. Raymond, 1996 Source-sink populations in Mediterranean blue tits: Evidence using single-locus minisatellite probes. J. Evol. Biol. 9: 965-978.

Edwards, S. V., 1992 Gene flow and mitochondrial DNA evolution in social babblers (Aves: Pomatostomus),. Ph. D. thesis, University of California at Berkeley.

Ellegren, H., 1996 First gene on the avian W chromosome (CHD) provides a tag for universal sexing of non-ratite birds. Proc. R. Soc. Lond. B 263: 1635-1641.

Evans, P. G. H., 1987 Electrophoretic Variability of Gene Products, Cooke, F. \& Buckley, P. A. (eds.) Avian Genetics-A Population and Ecological Approach: 105-162. Academic Press, London.

Fleischer, R. C., Fuller G. \& Ledig, D. B. 1995. Genetic structure of endangered clapper rail (Rallus longirostris) populations in Southern California. Conserv. Biol. 9: 1234-1243.

Frankel, O. H. \& Soulé, M. E. 1981 Conservation and Evolution. Cambridge University Press, Cambridge.

Frankham, R., 1996. Relationship of genetic variation to population size in wildlife. Conserv. Biol. 10: 1500-1508.

Grant, P. R. \& Grant, B. R. 1992. Hybridization of bird species. Science 250: 1394-1397.

Greenwood, P. J., 1987. Inbreeding, philopatry, and optimal outbreeding in birds., Cooke, F. and Buckley, P. A. (eds.) Avian genetics. A population and ecological approach: 207-222, Academic Press, London.

Griffiths, R. \& Tiwari, B. 1995. Sex of the last wild Spix's macaw. Nature 375: 454.

Haig, S. M., 1998. Molecular contributions to conservation. Ecology 79: 413-425.

Haig, S. M. \& Avise, J. C. 1996. Avian conservation genetics, Avise, J. C. and Hamrick, J. L. (eds) Conservation Genetics-Case histories from nature-: 160-189. Chapman \& Hall, New York.

Haig, S. M., \& Ballou, J. D. 1995. Genetic diversity in two avian species formerly endemic to Guam. Auk 112: 445-455.

Haig, S. M., Ballou, J. D. \& Derrickson, S. R. 1990. Management options for preserving genetic diversity: Reintroduction of Guam Rails to the wild. Conserv. Biol 4: $290-300$.

Haig, S. M., Belthoff, J. R. \& Allen, D. H. 1993. Examination of population structure in red-cockaded woodpeckers using DNA profiles. Evolution 47: 185-194.

Haig, S. M., Bowman, R. \& Mullins, T. D. 1996. Population structure of red-cockaded woodpeckers in south Florida: RAPDs revisited. Mol. Ecol. 5: 725-734.

Haig, S. M., Gratto-Trevor, C. L., Mullins, T. D. \& Colwell, M. A. 1997. Population identification of western hemisphere shorebirds throughout the annual cycle. Mol. Ecol. 6: 413-427. 
Haig, S. M., Rhymer, J. M. \& Heckel, D. G. 1994. Population differentiation in randomly amplified polymorphic DNA of red-cockaded woodpeckers Picoides borealis. Mol. Ecol. 3: 581-593.

Harmer, T. E., Forsman, E. D. Fuchs, A. D. \& Walters, M. L. 1994. Hybridization between Barred and Spotted Owls. Auk 111: 487-492.

Higuchi, H., Nagendran, M. \& Sorokin, A. G. 1994a. Satellite tracking of common cranes Grus grus migrating north from Keoladeo National park, India. Higuchi, $\mathrm{H} \&$ Minton, J.. (eds) The Future of Cranes and Wetlands: 26-31, Wild Bird Society of Japan, Tokyo.

Higuchi, H., Ozaki, K., Golvuskin, K., Goroshko, O., Krever, V., 1994b. The migration routes and important rest-sites of cranes satellite tracked from South-Central Russia. Higuchi, H. \& Minton, J.. (eds) The Future of Cranes and Wetlands: 15-25, Wild Bird Society of Japan, Tokyo.

樋口広芳. 1996. 保全生物学. pp253. 東京大学出版会. 東京.

Hill, A. V. S., 1991 HLA associations with malaria in Africa: some implications for MHC evolution., Klein, J. \& Klein, D. (eds.), Molecular evolution of the major histocompatibility complex: 403-420. Springer Verlag, New York.

石田 健. 1996. 鳥類の生態研究における DNA 研究一系統と保全遺伝学を中心に一山階鳥研報 28: $51-80$.

IUCN, 1996. The 1996 IUCN Red List of Threatened Animals. IUCN, Gland, Switzerland.

Jeffreys, A. J., Wilson, V. \& Thein, S. L., 1985 Hypervariable 'minisatellite' regions in human DNA. Nature 314: 67-73.

環境庁自然保護局, 1998.レッドデータブック，生物多様性情報システム．http://www.biodic.go. $\mathrm{jp} / \mathrm{rdb} / \mathrm{rdb} \_$f.html

国立遺伝研究所, 1999. 日本 DNA データバンク, http://www.ddbj.nig.ac.jp/Welcome-j.html

Krajewski, C., 1994. Phylogenetic measures of biodiversity: A comparison and critique. Biol. Conserv. 69: 33-39.

Lack, D., 1974. Evolution illustrated by waterfowl. Blackwell Scientific Publications, Oxford.

Lebreton, J.-D., 1993. Marked Individuals in the study of bird population. Birkhäuser, Basel/Switzerland.

Loeschcke, V., Tmiuk, J. \& Jain, S. K., 1994. Conservation Genetics. Birkhäuser, Ba sel/Switzerland.

Mace, G. M., Smith, T. B., Bruford, M. W. \& Wayne, R. K., 1996. An Overview of the lssues, Smith, T. B. \& Wayne, R. K. (eds) Molecular Genetics Approaches in Conservation: 3-21. Oxford University Press, New York.

Martin, G., 1996. Birds in double trouble. Nature 380: 666-667.

Meffe, G. K. \& Carroll, R. C., 1994. Principle of Conservation Biology. Sinauer Associates, Sunderland, Massachusetts.

Murata, K., Itoh, Y. Ogawa, A. \& Mizuno, S., 1998. Sexing the Oriental White Stork Ciconia boyciana by PCR using a single plucked feather as a source of DNA. Jpn. J. Ornithol. 46: 157-162.

Nei, M., 1987 Molecular Evolutionary Genetics. Colimbia University Press, New York. 「邦訳 : 根井正利, 1990.分子進化遗伝学 (五条堀孝・斎藤成也共訳), p.433, 培風館, 東京」

$\mathrm{NIH}$, National Center for Biotechnology Information, http://www.ncbi.nlm.nih.gov/ 西海 功, 1997. DNA 多型分析の生態学への応用, pp.158-170. 山岸 哲編, 鳥類生態学入門: 観察 と研究のしかた, 築地書館, 東京.

Parker, P. G., Snow, A. A. Schug, M. D. Booton, G. C. \& Fuerst, P. A., 1998. What molecules can tell us about populations: Choosing and using a molecular marker. Ecology 79: 361-382.

Primack, R. B., 1993. Essential of Conservation Biology. Sinauer Associates, Sunderland, Massachusetts. 
Rhymer, J. M., Williams, M. J. \& Braun, M. J., 1994. Mitochondrial analysis of gene flow between New Zealand mallards (Anas platyrhynchos) and grey ducks ( $A$. superciliosa). Auk 111: 970-978.

Savidge, J. A., 1987. Extinction of an island forest avifauna by an introduced snake. Ecology 68: 660-668.

Seutin, G., White, B. N. \& Boag, P. T., 1991. Preservation of avian blood and tissue samples for DNA analyses. Can. J. Zool. 69: 82-90.

Signer, E. N., Schmidt, C. R. \& Jeffreys, A. J., 1994. DNA variability and parentage testing in captive Waldrapp ibises. Mol. Ecol. 3: 291-300.

Smith, T. B., \& Wayne, R. K., 1996. Moleculor Genetic Approaches in Conservation. Oxford University Press, New York.

Soule, M. E., 1976 Allozyme variation, its determinats in space and time., Ayala, F. J. (ed) Moleculor Evolution: 60-77. Sinauer Associates, Sunserland, Massachusetts.

Soule, M. E., 1986. Conservation Biology; The Science of Scarity and Diversity. Sinauer Associates, Sunderland, Massachusetts.

Tarr, C. L., Conant, S. \& Fleischer, R. C., 1998. Founder events and variation at microsatellite loci in an insular passerine bird, the Laysan finch (Telespiza cantans). Mol. Ecol. 7: 719-731.

Tarr, C. L. \& Fleischer, R. C., 1993. Mitochondrial DNA variation and evolutionary relationships in the 'Amakihi' complex. Auk 110: 825-831.

Tegelström, H., \& Sjöberg, G., 1995. Introduced Swedish Canada geese (Branta canadensis) have low levels of genetic variation as revealed by DNA fingerprinting. J. Evol. Biol 8: 195-207.

Triggs, S. J., Williams, M. J., Marshall, S. J. \& Chambers, G. K., 1992. Genetic structure of blue duck (Hymenolaimus malacorhynchos) populations revealed by DNA fingerprinting. Auk 109: 80-89.

Ueta, M., Sato, F., Lobkov, E. G., \& Mita, N., 1998 Migration route of White-tailed Sea Eagles Haliaeetus albicilla in northeastern Asia. Ibis 140: 684-686.

熟谷いずみ・矢原徹一.1996.保全生態学入門. p270.文一総合出版. 東京.

Westneat, D. F. \& Webster, M. S., 1994 Molecular analysis of kinship in birds: Interesting questions and useful techniques, Schierwater, B, Streit, B., Wagner, G. P. \& DeSalle, R., (eds) Molecular Ecology and Evolution Approaches and Applications: 91-126 , Birkhaüser Verlag, Basel/Switzerland.

Williams, M., 1991 Social and demographic charcteristics of Blue Duck, Hymenolaimus malacorhynchos. Wildfowl 42: 65-86.

Williamson, M., 1996. Biological Invasion. Chapman \& Hall, London.

Wright, S., 1931 Evolution in Mendelian populations. Genetics 16: 97-159.

山階鳥類研究所, 1997.渡り鳥アトラス (スズメ目編1961年 1995年), 山階鳥類研究所, 我孫子.

Zink, R. M. \& Kale, H. W., 1995 Conservation genetics of the extinct dusky seaside sparrow Ammodramus maritimus nigrescens. Biol. Conserv. 74: 69-71. 
付表 : 遗伝的多梯性を計測する時に用いられる尺度

個体群内および種内の遺伝的多様性の尺度

$P:$ 多型遺伝子座の割合

$A P$ : 多型遗伝子座あたりの平均対立遺伝子数

$A$ : 遺伝子座あたりの平均対立遺伝子数

$A_{e}:$ 遺伝子座あたりの有効対立遺伝子数 $\left(1 / \Sigma p_{i}^{2}\right)$

$\mathrm{H}_{\mathrm{o}}$ ：個体当たりのへテロ遺伝子座の割合

$\mathrm{H}_{\mathrm{e}}$ : ハーデイ・ワインベルグ平衡時のヘテロ遺伝子座の割合の期待值 $\left(1-\Sigma p_{i}^{2}\right)$

個体群間の遺伝的多様性の尺度

$F_{\mathrm{ST}}$ : 個体群間の遗伝子頻度の標準分散

$$
F_{\mathrm{ST}}=\frac{\sigma_{p}^{2}}{\bar{p}_{i}\left(1-\bar{p}_{i}\right)}
$$

$\sigma_{p}^{2}$ : 対立遺伝子の個体群間の分散, $\overline{\boldsymbol{p}}_{i}: i$ 番目の対立遺伝子の平均頻度

$F_{\mathrm{ST}}$ は個々の遺伝子座および対立遺伝子ごとに計算される．

集団間の類似度および遺伝的距離

$I:$ 遗伝的類似度 $(0 \leqq I \leqq 1)$

$$
I=\frac{\sum x_{i} y_{i}}{\sqrt{\sum x_{i}^{2} \sum y_{i}^{2}}}
$$

$x_{i}, y_{i}$, は, 集団 $x, y$ 中での対応する $i$ 番目の対立遺伝子の割合.

$D:$ 遺伝的距離 $\quad D=-\ln I$

$S:$ ロジャーの遺伝的距離

$$
S=1-\frac{1}{\sqrt{\Sigma\left(x_{i} \cdot y_{i}\right)^{2}}}
$$

